\title{
HoW CAN Higher EdUCATION CONTRIBUTE TO Good Governance in DEVELOPING COUNTRIES?
}

\author{
Paper presented at the Annual Conference of the European \\ Association for International Education (EAIE); University \\ of Tampere, Finland, December 2001.
}

\section{Dirk BEKE}

Ghent University, Sub-Department of Non-Western Law \& Antwerp University, Institute of Development Policy and Management - Belgium

\section{E-mail: Dirk.Beke@rug.ac.be}

Teaching good governance for developing countries raises a profound dilemma. Development partners in the North underline the importance of the creation of a democratic government, separation of powers, the rule of law. Governments and partners in the South often assert that good governance demands first of all an 'efficient' administration to implement government policy. For them, teaching and training should focus largely on the techniques of good public management, with priority given to aspects such as efficiency, professionalism, quick implementation and low costs.

There is no doubt that good governance needs an adequate administration. The reality, however, shows that improving public administration doesn't necessarily lead to better governance. On the contrary, creating a well-run administration that is serving unjust political ideas and authoritarian practices risks producing bad 
governance. An example will be given based on the recent processes of decentralisation in developing countries.

The aim is to open a debate on the following question: How can higher educational institutions in developing countries and their partner institutions in the North find a common input and programme that can contribute to the real improvement of governance?

\section{The two components of good governance: good politics and good administration}

Good politics includes the existence and further elaboration of political structures and practices for the realisation of good policy. Good administration consists of efficient administrative structures and procedures for the correct implementation of that policy. A part of the administration also has the task of informing policy-makers, collecting opinions and formulating concepts which can feed into policy-making.

Although politics and administration are two different concepts, they interact closely. In addition, they frequently have common elements. For instance, good politics is based on openness in the decision making process (e.g. public debate in parliament, free press) and a good administration is an open administration (e.g. clear information for the public, public access to documents).

Economists should bare in mind that to avoid confusion, I do not classify the concepts 'good economic policy' and 'good economic management' under the specific idiom of 'good governance'. But this doesn't mean that we underestimate their interaction. An economic programme for poverty alleviation needs and should be based on good governance and its implementation will require an efficient administration.

Regarding the role of the state, we should remark that the present tendency towards more 'privatisation' doesn't mean a reduction in the importance of the state. The state continues to be the main actor 
responsible for good governance. The French specialist in public administration, Guy Braibant, emphasises that 'governance' means that: (1) the state is, first and foremost, responsible for the regulation of economic life - the market economy system does not reduce the need for regulation; on the contrary, it increases this need -; (2) the state has a unique part to play in ensuring social cohesion; (3) the state must protect the environment and guarantee sustainable development; (4) finally, the state remains the essential actor on the international scene. ${ }^{1}$

Two lists will help us to clarify the difference between 'good politics' and 'good administration'.

\section{The meaning and contents of good politics}

It is not my aspiration here to formulate a conclusive definition of good politics, nor to offer a complete list of its elements. On the contrary, I hope that this open list will be supplemented with additional elements, especially with proposals from Southern partners. The order of classification is tentative and must be discussed and undoubtedly modified.

Good politics includes:

- a policy based on the realisation of basic human needs and social justice;

- a democratic decision making, with free elections;

- the separation of powers, including political accountability

- $\quad$ and an independent judiciary;

- the rule of law, with guarantees for security and peace

- and easy access to courts;

- a strong judiciary;

${ }^{1}$ Guy Braibant: Public administration and development, In: International Review of Administrative Sciences (SAGE, London, Thousand Oaks and New Delhi), Vol. 62 (1996): 163-176. 
- a respect for human rights, including the protection from discrimination, gender equality, freedom of opinion and expression and cultural self determination;

- a realistic and well balanced state-budget, with fiscal accountability;

- local autonomy, devolution / decentralisation;

- the recognition of autonomous pressure groups, associations and NGOs.

\section{The meaning and contents of good administration}

Good administration is more than management techniques. A public administration should have its focus on the citizens. The following elements are tentatively suggested:

- an efficient administrative apparatus, with basic infrastructure and competent civil servants;

- efficient management, including planned and co-ordinated efforts, creativity and the ability to innovate, and low costs;

- an efficient administration of justice, with sufficient crime prevention and treatment of offenders;

- a people-centred administration, including active participation of the elected representatives of the people, consultation, partnership and the existence of an ombudsman;

- the use of relays such as (independent) associations, trade unions and NGOs;

- an open administration, with clear information actively made available to the public, with systems for monitoring results and with public access to documents

- the different forms of accountability: (1) political accountability to the political authorities - parliament, government and political parties - and to the citizens, (2) civic accountability, (3) disciplinary and penal responsibility, (4) financial accountability;

- decentralisation / devolution;

- focus on an 'endogenous' administration (the grafting of modern elements onto indigenous elements). 


\section{Good governance in developing countries}

Good governance is one of the strategies being used to promote human rights and democracy. ${ }^{2}$

One of the main targets of good governance is the 'domesticating' of the state. In the interesting study 'The Self-Restraining Sate', Andreas Schedler writes: Domesticating the state, subjecting it to effective institutions of 'self-restraint' runs against the entrenched interests of powerful actors and thus sparks conflict and provokes resistance. ${ }^{3}$

For a clear and relatively complete understanding of the present perception of 'development', we can refer to the UN-declaration of 1986: Development is a comprehensive economic, social, cultural and political process, which aims at the constant improvement and the well-being of the entire population of all individuals on the basis of their active, free and meaningful participation in development and in the fair distribution of benefits resulting therefrom. ${ }^{4}$

Among the many attempts to formulate a definition of 'good governance', the following meaningful and condense formulation is worth quoting: Sensible economic and social policies, democratic decision-making, sufficient governmental transparency, fiscal accountability, creation of a market-friendly climate for development, measures to combat corruption, and respect for the rule of law and of

\footnotetext{
${ }^{2}$ Swanson, Alan D. , Good governance and human rights in development and democracy, In: Eugene Cotran and Adel Omar Sherif (eds.) Democracy, the Rule of Law and Islam, Kluwer Law International, 1999: 331-341.

${ }^{3}$ Schedler, Andreas. "Restraining the State: Conflicts and Agents of Accountability", In: Andreas Schedler, Larry Diamond \& Marc F. Plattner (eds.), The Self-Restaining State. Lynne Rienner, Boulder / London, 1999, 333-350: 345.

4 Declaration on the Right to Development, U.N. General Assembly Resolution 41/128, 4 December 1986.
} 
human rights. ${ }^{5}$ Another creative definition of 'good governance' is formulated in the 1994 Agenda for Development (UN), wherein it is stated that that good governance involves: the wisdom and the historical responsibility to know when the marked forces act, when to let civil society take the lead, and when government should intervene directly. ${ }^{6}$

During discussions about good governance at the end of the nineties, the concept is becoming increasingly linked with the notion of participation and decentralisation. In the framework of European cooperation, the Council of Europe has outlined the following criteria for accepting cooperative initiatives:

- countries which are attempting to institute democracy and improve their human rights performance;

- the holding of elections, the setting-up of new democratic institutions and the strengthening of the rule of law;

- the strengthening of the judiciary, the administration of justice, crime prevention and the treatment of offenders;

- promoting the role of NGOs and other institutions which are necessary for a pluralist society;

- the adoption of a decentralised approach to cooperation;

- $\quad$ ensuring equal opportunities for all. ${ }^{7}$

5 Ginther, Konrad; Erik Denters and Paul J.I.M. de Waart (eds.) Sustainable Development and Good Governance, Dordrecht, 1995: 1; citation in Swanson, 1999: 332.

${ }^{6}$ Ginter, Denters \& de Waart: 5; geciteerd in Swanson, 1999: 332.

${ }^{7}$ Democracy and development, Bull. EC11-1991, p.122; citation in Swanson, 1999: 332. 


\section{The development of administration and the administration of development}

A brief analysis of the content and the experiences during the last decades of development administration in developing countries confronts researchers and advisers with an apparent vicious circle. In the sixties, one of the founders of 'development administration' W.F. Riggs already referred to the two faces of development administration. ${ }^{8}$

- The development of administration means the strengthening and improving administrative capabilities.

- The administration of development is an instrument in the implementation of development programmes, projects and policies, in other words 'development tasks'.

And Riggs concludes by mentioning: the reciprocal relatedness of these two sides involves a chicken and egg type of causation. An obvious answer could be that the two faces are mutually supportive of each other. However, the question remains of where to start or what should be emphasised in an environment with few or no financial and human resources.

\section{The difficult relation between politics and administration}

Another dilemma related to the concepts and practises of good governance and good administration in developing countries is the problematical relation between politics and public administration.

To explain the problem, we do well to refer to the thesis that has been formulated by W.F.Riggs. The authors' stating point is: that premature or too rapid expansion of the bureaucracy when a political

\footnotetext{
${ }^{8}$ Sapru, K.S.: Development Administration, New Delhi, Sterling, 1994: 120 - 139.
} 
system lags behind tends to inhibit the development of effective politics. A corollary thesis holds that separate political institutions have a better chance to grow if bureaucratic institutions are relatively weak. ${ }^{9}$

A fuller explanation by Riggs can clarify this controversial reasoning: The view taken here is not, of course, that bureaucrats or bureaucracy are essentially evil monsters, and certainly the need for administrative services which can be performed only by public officials argues for an expansion and improvement, not curtailment, of bureaucracy. The argument is presented, however, that effective administration by bureaucrats is contingent upon the simultaneous growth of extrabureaucratic institutions capable of maintaining effective control over officials, of keeping them responsible to the formal political authorities, and responsive to the public an clientele interests directly affected by their work. Ideally, such responsibility is to the whole population through democratic processes ... ${ }^{10}$

The conclusion of Riggs gives us a clear insight into the necessity importance of, or at least the potential for 'good politics' for the development of 'good administration' and of the dangers of (exclusively and pure) fast economic growth. It may be that political development, at least toward a democratic type of political action, can be attained only at the cost of slower economic and social development. It is often said that authoritarianism can force economic development at a more rapid rate than democracy. Less familiar is the corollary that efforts to speed the rate of economic development may lead toward bureaucratic authoritarianism. ${ }^{11}$

\footnotetext{
${ }^{9}$ Riggs, Fred W. "Bureaucrats and Political Development: A Paradoxical View"; in: Bureacracy an Political Development, Princeton, Princeton University Press, 1967, $120-167: 126$.

${ }^{10}$ Riggs, 1967: 126, note 11 .

${ }^{11}$ Riggs, 1967: 135.
} 


\section{Decentralisation in Uganda}

The decentralisation process in Uganda gives us an interesting overview of the complex relation between politics and administration. A study conducted for the Belgian Department of Development Cooperation $^{12}$ showed us that decentralisation can easily become a pretext to pass on public tasks to non-governmental actors (NGOs). We also observed that (potentially good) decentralisation techniques can be manoeuvred by the central state to increase its control over the population. The study of the results of the ongoing decentralisation process in Uganda, however, demonstrates that in the longer term decentralisation can weaken the control exercised by state bureaucracy and result in more guarantees for political development.

It is clear that the Ugandan government is using decentralisation as a step in a process of passing on public functions to NGOs and other actors in the civil society (société civile) and even to private companies. The local entities are receiving more and more responsibilities, apparently with the idea - or hope - that they won't be able to cope with all these, and will therefore have to ask for the assistance of these other bodies. The idea is that at the local level there is a better view of the necessities, capacities and potential entrepreneur-ship. This may well be true. But the passing on of responsibilities is taking place also because it offers the pleasing prospect of saving on the national government's budget.

The present nearly unlimited mobilisation of non-governmental actors raises questions about co-ordination and, more importantly, about the lack of democratic structures, transparency and accountability. These organisations are almost never accountable to the local population. ${ }^{13}$ There is a real danger that the supervision, control and auditing of

\footnotetext{
12 The study is the result of a research project on decentralisation in Uganda done in 1998-1999; see: D. Beke, D. Deprez \& J.L. Grootaers: Lokaal en intermediair endogeen bestuur. Deelrapport Uganda. Gent, RUG / VLIR / DGIS, 2001.

${ }^{13}$ Mamdani, Mahmoud: The Politics of Democratic Reform in Uganda. East African Journal of Peace \& Human Rights, 1996, nr. 2/1, 91-101: 94.
} 
administration as carried out within the official decentralised structures will be de facto neutralised. Indeed, interviews and reports show this already happening. In a few cases non-governmental actors use their strong (financial) position to influence local policy to their own benefit. In addition, attention has been drawn, mainly by foreign NGOs,${ }^{14}$ to the paternalistic attitude, the pursuing of short term goals, and the focus on activities at a micro-level, rather than on long term economy, policy and social service at a macro level. We can conclude that building up a better administration through the mobilisation of non-governmental actors has not created better politics. In fact, the opposite has occurred.

Another important conclusion is that the use of decentralisation for the purpose of both the creation and the control of a local sphere of power has established new administrative structures which, intended or not, offer new possibilities for local countervailing powers. The history of the decentralisation in Uganda shows that after the coming into power of Yoweri Museveni's National Resistance Movement (NRM) in 1986, local resistance councils were incorporated in an official process of decentralisation. The new regime clearly saw the development of decentralised authorities as a means to strengthen the power of the central government at the local level. This mainly top-down process of formal decentralisation, however, has quite soon generated its own local dynamism. The development of grassroots structures and participation through the NRM Resistance Councils and Committees has, to a great extent, opened up possibilities for the population to exert pressure on the state, in spite of the top-down way in which these structures were imposed. These local countervailing powers have clearly found a new way in which to regulate decentralisation. During elections, for example, many candidates coming from outside the NRM participated. In spite of the frequent manipulations and abuse of administrative privileges by the NRM, and in spite of the de facto monopoly of the NRM to act - at the local level - as an organised political 'party', in many of the local authorities, NRM officials were voted out. A direct and logical consequence of this

\footnotetext{
${ }^{14}$ Okola-Onyango, Joseph and J.J. Barya. Civil Society and the Political Economy of Foreign Aid in Uganda. Democratization, 1997, nr. 4/2, 113-138: 134-135.
} 
process is the demand of these elected councils for greater autonomy, as well as the demand that the legally established decentralisation principles be properly executed.

\section{The dangers of an efficient administration under a perverse political regime}

A frightening example of the sensitive relation between politics and administration is the organisation of the genocide in Rwanda.

The course of the terrible events in 1994 shows that the well-established and efficient administrative decentralisation (or déconcentration) towards the communes was the main vehicle used by the Hutuextremists to accomplish the genocide of the Tutsi minority and the murder of moderated Hutu politicians, civil servants and human rights activists. The efficiency of that administrative decentralisation also appeared later in the Hutu-refugee camps abroad. The former Rwandan municipalities with their administrative structures and their mayors, were transplanted to these various camps for the internal organisation and socio-political control of their Hutu residents in exile.

\section{The donors role in the process of good governance}

UNDP has developed a number of interesting recommendations concerning the donors' role in the processes of decentralisation in Third World countries. ${ }^{15}$ These recommendations seem to be valuable not only for decentralisation but also for the broader process of good governance. An adaptation of these UNDP recommendations brings us to the following conclusions: Good governance is a sensitive

\footnotetext{
${ }^{15}$ Factors to Consider in Designing. Decentralised Golernance Policies and Programmes to Achieve Sustainable People-Centred Development. Management Development and Governance Division, United Nations Development Programme. New York, February 1998.

http://magnet.undp.org/Docs/dec/DECEN923/Factors l.htm - 2001.
} 
national issue. Donors should not attempt to control this process but rather play a facilitative role. They should see good governance as a learning process and should allow for mistakes to be made and learning to take place. They should take an approach involving process consultation approach in the design of programmes involving the national and local actors in each phase of the programme for good government.

In addition, it is essential that donors should carefully examine actual political practices and evaluate not simply the present degree of good governance but rather the signs of progress, of evolution of good governance. They should compare the present situation with the situation in former years.

There is no doubt that good governance needs an adequate administration. But the donors must be aware that improving public administration doesn't necessarily lead to better governance. On the contrary, creating a well-run administration that is serving false political ideas and practices risks producing bad governance.

\section{Conclusions - What kind of teaching and training?}

Teachers and trainers are confronted by conflicting demands. Teaching administration (public management) should go together with teaching basic principles of 'good politics'. Programmes should be based on the comparative study of models and reforms in both the North and the South.

The Public Administration curriculum has become increasingly 'globalised' presenting opportunities for transferability in terms of programme and content (New Public Management). Good governance teaching must have both a global perspective and a particular perspective (decentralisation). 
Decentralisation requires public administration which is sensitive to local cultures, needs and practices. Teaching and training good governance (especially local governance) will need active local participation, field studies and intensive study visits for exchange of views with local officials and members of the civil society (NGOs).

And last but not least: the programmes, schools and institutes should practice the principles of good governance themselves. 